Published in "Social Science \& Medicine" 71(2), 2010, 236-243

which should be cited to refer to this work

\title{
Between the lines: Republicanism, dissenters and the politics of meta-trauma in the Northern Irish conflict ${ }^{q}$
}

\section{Olaf Zenker*}

Institute of Social Anthropology, University of Bern, Laenggassstrasse 49a, 3012 Bern, Switzerland

\section{Introduction}

In his intriguing study exploring identity, culture and suffering with a displaced Kashmiri Sikh, Aggarwal (2007) draws attention to the problem of how to evaluate the accuracy of information garnered in verbal communication. Arguing from within crosscultural psychiatry, he suggests analysing both the 'spoken text' for informational content and the 'unspoken subtext' for interactional context, putting special emphasis on the dynamics between

\footnotetext{
q I am grateful to the Max Planck Institute for Social Anthropology in Halle, Germany for financially supporting as well as intellectually inspiring my research, which produced the data on which this text is based. Reem AL-Botmeh, Édouard Conte, Goran Dokic, Julia Eckert, Markus Hoehne, Thamar Klein, Patrick Neveling, Catherine Panter-Brick, Steve Reyna, Julia Zenker, Heinzpeter Znoj as well as five anonymous reviewers provided insightful comments on earlier versions of this text. Last but not least, I also wish to thank Dónal for sharing his story with me.

* Tel.: p41316313632.

E-mail address: zenker@anthro.unibe.ch
}

transference and countertransference during psychiatric interviews.

Aggarwal addresses a general quandary in social science research that has a long methodological history. Within life story research e the field in which this article is situated e an earlier analytical emphasis on 'the telling of the truth', i.e. Aggarwal's informational content, has increasingly given way to focusing on 'the truth of the telling', i.e. Aggarwal's interactional context (Frank, 1995). Yet as Peacock and Holland (1993) argue, accounts need to be investigated with regard to context as well as content given that both aspects are mutually implicated. Thus, whether one is more interested in the interactional context of communicative acts or the informational content conveyed in such accounts, each focus methodologically requires the other as its background; both sides need to be simultaneously reconstructed in an analytical strategy of mutual interpretation that aims at both internal analysis and external triangulation. However, the decision to foreground either the interactional context or the informational content impacts the scope that analysis of these interactional encounters can occupy in the actual presentation of results. 
This article largely foregrounds the informational content of a number of in-depth life story interviews with one person, a key informant and friend from my ethnographic fieldwork in 2003-2004 in Northern Ireland, a man in his late forties whom I shall call Dónal. The interactional context of our encounters thus somewhat backgrounded in this article, this context is still repeatedly addressed, especially at the end of my analysis, reconfiguring the reconstructed information in the light of our interactional encounters. For now, suffice it to say that I experienced interviews with several informants as quite specific - and those with Dónal were merely paradigmatic in this respect -, in that empathically asking questions about identity and suffering triggered certain, often highly emotional interactions precisely because I thereby configured a speaker position that was usually not existent for my interview partners. Making sense of these peculiar encounters, this article ultimately suggests that they should be treated as symptomatic of a much broader mismatch between individual attempts to come to terms with traumatic experiences and socio-culturally hegemonic forms of processing such experiences.

'Trauma' as such did not constitute the main focus of my fieldwork. Instead, I had come to Belfast to investigate the construction of ethnicity throughout the Northern Irish conflict - the so-called 'Troubles' - that had violently erupted in 1969 and passed into a more hopeful phase with the peace process of the 1990s. However, despite recent changes, local society remained deeply divided and remains so today. This divide can be characterised according to three dichotomies, namely, in terms of religious background, ethnic identity and political aspirations. The first dichotomy separates the local population along the lines 'Catholic' versus 'Protestant' religious backgrounds. In the second, an almost exclusively Catholic part of the population sees itself as 'Irish,' whereas Protestants mainly characterise themselves as 'British.' In the third, most local Irish can be described politically as 'Nationalist' or 'Republican'; both positions aspire for a united, independent Ireland but differ on the issue of political violence, with 'Republicanism' considering it as a legitimate means. In contrast, the majority of the 'Unionists' or 'Loyalists' advocate the maintenance of 'the United Kingdom of Great Britain and Northern Ireland,' with only 'Loyalism' also advocating physical violence (Coulter, 1999: 10-22). As public opinion data shows (Coakley, 2007), there has been a far-reaching homology between 'Catholic,' 'Irish' and 'Nationalist/Republican,' on the one hand, and 'Protestant, 'British' and 'Unionist/Loyalist,' on the other. Yet variations and cross-cuttings do exist and provide the basis for precisely those tensions that are of interest in this article.

In cities like Belfast, the overall social divide is manifested in considerable residential segregation (Doherty \& Poole, 2000: 189). This particularly applies to West Belfast, where I did fourteen months of fieldwork on the relationship between the Irish language and Irishness (Zenker, 2008, 2009, 2010). This part of the city consists of two areas - a Protestant one to the north and a Catholic area to the south - physically separated by so-called 'peace lines' across which interaction continues to be limited. It is hence not surprising that virtually all my informants in Catholic West Belfast came only from the Irish Nationalist/Republican community. What is more, Catholic West Belfast is widely perceived as one of the radicalised heartlands of Irish Republicanism.

Regarding the methods of data collection, I used both participant observation and informal interviews for contextualising an extensive series of in-depth life story interviews with a total of twenty-eight key informants. In order to ensure a more representative sample, I selected interviewees according to age, gender and class. Regarding the interactional context of these interviews, it was striking that many of my interlocutors, while adjusting their accounts to our specific encounters, evidently reproduced largely preconceived positions and articulated personal experiences of violence mainly in Nationalist terms that ascribed primary responsibility for the Troubles to the oppressive British state. Yet during other interviews the interactional context was markedly different in that my interlocutors rather clarified and thereby produced for themselves their positions in our interactions and often explicitly commented on this very fact. During such encounters, several interlocutors talked about their traumatic experiences in decidedly non-Nationalist ways, and this was especially the case with Dónal, whose exemplary case I will focus on in the remainder of this article.

In the course of both data collection and subsequent analysis, the material relevant for this article was source-critically evaluated regarding its validity in a twofold way: first, with regard to the mutual implication of interactional context and informational content, as described above; and second, in terms of a triangulation that tested the reliability of Dónal's accounts by scrutinising their internal consistency and by comparing them with data obtained from other informants, archival material as well as the existing literature. With regard to the analytic strategy during data analysis, I followed a grounded theory approach (Glaser \& Strauss, 1967), in identifying analytic categories through inductive coding and consolidating, through memoing, the coded data into a 'grounded' interpretation of how Dónal's identity troubles developed and played out in the specific context of West Belfast. In accordance with this methodology, the verbal quotations in this article were selected as 'exemplars' of the thus created and source-critically validated 'grounded theory'. While I did not seek institutional review (which is not required within anthropological research in Germany), I conducted my research in accordance with the ethical guidelines of the Association of Social Anthropologists of the UK and the Commonwealth. Furthermore, Dónal read the manuscript of this article and gave explicit consent to publication.

I first met Dónal just after my arrival in Belfast at an Irishlanguage course, and in the coming months we repeatedly met and conversed informally in various Irish-language contexts. In addition, we arranged for a total of five extensive interviews, each of which lasted three to four $h$. These tape-recorded interviews, taking place between autumn 2003 and summer 2004, took on a decidedly unstructured and, at times, strongly emotional character (e.g. when Dónal cried), with me participating largely as an active listener. All verbal quotations provided in the following are taken from transcripts of these interviews.

During our first interview in October 2003, Dónal realised that he had never told his story before. He explained that even though some people had suffered very directly in the course of the Troubles, 'all of us have been impaired; we are all painted shades of the victim colour.' According to Dónal it was ultimately impossible to say whether people living in areas like West Belfast, where violence had occurred frequently, 'were somehow more traumatically affected' than people who experienced only one incident 'because of the trauma of this one thing.' Dónal seemed convinced that all people in the North of Ireland had lost something as a result of the Troubles, and, as he emphasised, 'a lot of people have not had the opportunity to tell their personal story.' Yet he insisted, 'you do need to tell it, even if you only tell it once. Because it's a pent-up thing that you have got in there that needs to be spoken out loud.' As we will see, Dónal's choice to call himself 'European' rather than 'Irish' directly followed from this whole idea of 'trauma' and victimhood, given that, as he phrased it, 'the Irishness that I have, has been severely damaged by the trauma that I experienced throughout that whole process.'

In this interview, Dónal drew on the biomedical discourse of 'trauma' in order to make sense of his painful experiences. The notion of 'trauma' as referring to a mental injury first emerged in late nineteenth century Western psychiatry in relation to clinical 
symptoms of hysteria. Yet as an acknowledged psychiatric phenomenon, it gained general acceptance only in 1980, when the diagnosis of 'post-traumatic stress disorder (PTSD)' was officially introduced in the American Psychiatric Association's Diagnostic and Statistical Manual of Mental Disorders (DSM-III). By that time mental health workers had lobbied effectively on behalf of Vietnam War veterans to get their war-related trauma acknowledged as a psychological malady (Herman, 1992: 7-132; Young, 1995: 5).

Within the recent Diagnostic and Statistical Manual of Mental Disorders (DSM-IV), PTSD is defined in terms of a direct connection between a traumatic experience - such as a serious threat to one's life or physical integrity or witnessing violence - and a set of psychiatric symptoms, including re-experiencing the traumatic event and symptoms of arousal as well as of withdrawal (American Psychiatric Association, 1994: 427). PTSD is thereby represented as having a timeless and universal reality merely 'discovered' by Western biomedical science (e.g. in Herman, 1992). Critics have claimed, however, that the reality of 'trauma' and PTSD should instead be seen as a product of Euro-American science, which has only been 'universalised' within Western public health systems and through the globalised humanitarian agendas of governments and NGOs (Bracken, Giller, \& Summerfield, 1995; Summerfield, 1999; Young, 1995).

It is to this biomedical discourse of trauma that Dónal was obviously referring in our interviews. However, it soon became apparent that his invocation of this trauma discourse was aspirational rather than based on a well-established local pattern for making sense of painful experiences. This is not to say that trauma and PTSD did not form part of the biomedical toolkit of the Northern Irish National Health Service - they did. Following recommendations by the Social Services Inspectorate Report 'Living with the Trauma of the Troubles' (1998), a number of Trauma Advisory Panels had also been set up, coordinating the local provision of health and social services for people affected by the Troubles. However, as the recently published Eames and Bradley Report (2009: 88) observes, 'much more needs to be done in the area of post traumatic stress: to create a greater understanding of trauma; to ensure effective responses to it; to ensure adequate service provision and accessibility of those services.' My own experiences in Catholic West Belfast somewhat reflect this observation, in that the medicalisation of suffering in terms of psychological trauma did not really set the dominant terms in which traumatic experiences were being processed in everyday life. Instead, the local scene seemed to be rather dominated by another 'socio-culture of trauma.'

Recent transdisciplinary research on social suffering, violence and subjectivity has argued for the collapse of older dichotomies separating 'the individual from social levels of analysis, health from social problems, representation from experience, suffering from intervention' (Kleinman, Das, \& Lock, 1997a: x), and emphasised that cultural representations, social experiences and political processes are interlinked through complex power relations (Das, Kleinman, Ramphele, \& Reynolds, 2000; Das, Kleinman, Lock, Ramphele, \& Reynolds, 2001; Kleinman, Das, \& Lock, 1997b). Following this lead, this article focuses on the interplay between socio-culturally pre-structured lifeworlds of individuals and their varied attempts to come to terms with their traumatic experiences. For this purpose, the notion of 'socio-culture of trauma' might be a helpful concept in referring not only to culturally specific ways of handling experiences of suffering under the social condition of mass traumatisation in (post-)conflicts. Rather, such a socio-culture of trauma also is comprised of conflicting cultural strategies of narrating and/or eclipsing collective traumata - moving, so to speak, between 'chosen trauma' (Volkan, 1991) and 'chosen amnesia' (Buckley-Zistel, 2006) - that become socially hegemonic to differing extents, depending on the degree to which individual strategies secure backing from powerful political stakeholders. It is in the context of such socio-cultures of trauma, thus conceived of in terms of a person-centered cultural psychology informed by Gramsci's (1971) notion of hegemony (Gjerde, 2004; Hammack, 2008), that individuals have to continuously reconstruct their traumatised identities in conflict-ridden societies.

As I will show in the following, it is in relation to the specific socio-culture of trauma in Catholic West Belfast, largely dominated by Irish Republicanism, that both Dónal's difficulties in describing himself as 'Irish' as well as his attempts to activate a transcending biomedical trauma discourse for all victims in Northern Ireland need to be seen. While Dónal could thereby de facto not process his experiences in terms of trauma, I will ultimately argue that his problematic sense of identity was nevertheless still indexical of a truly 'psychosocial trauma', understood with Martín-Baró (1994: 108-135) as emergent as a mental health issue in the dialectical relationship between the individual and its socio-cultural environment, which in the very specific configuration of Dónal's case may be identified as 'meta-trauma'.

This argument is developed in three steps: first, I characterise Dónal's profound difficulty describing himself in terms of ethnicity, which became apparent during our encounters. I show how he experienced himself as caught 'between all stools' in that he could not identify with what he felt strongest about - namely, being 'Irish' - because of Republican violence conducted in the name of 'the Irish.' Not feeling 'British' either, he ended up calling himself 'European,' even though this label profoundly and very sadly lacked any personal depth. Second, I suggest that Dónal's difficulties should be interpreted less in terms of an individualised failure to cope psychologically but rather as also resulting from Dónal's sociocultural position 'between the lines:' his way of handling traumatic experiences did not square up with the hegemonic Republican trauma narrative but instead read 'between its lines' of empowered meanings. Thereby de facto establishing a counter-narrative, Dónal also positioned himself 'between the (front-)lines' of meaningful power. This awkward position led to encounters characterised by incomprehension, threatening silence and repudiation. Third, I conclude that Dónal's persistent inability to socio-culturally integrate his traumatic experiences needs to be interpreted against the politicised background of this specific socio-culture of trauma rather than misconceived as merely rooted in the personal failures of a sensitive man. I use the term 'meta-trauma' to refer to this socio-culturally conditioned 'second' trauma of repeatedly failing to integrate one's own traumatic experiences - a term meant both as a description of the specific socio-cultural place of such an affliction and as a means for thereby integrating and possibly overcoming it.

\section{Between all stools: Dónal and his personal troubles with Irishness}

From early on it became clear that Dónal lacked a sense of selfevident, stable and continual Irishness comparable to that expressed by many of my other informants. Instead, our interviews often leaned towards presently making sense of past experiences in terms of his ethnic identity. Eventually, this resulted in an overall shift between two positions, which Dónal came to see as alternatives, while I conceive(d) them rather as complementary sides of the same configuration. Before addressing this disagreement, I will first refer to some of Dónal's more straightforward experiences that formed the backdrop for his personal troubles with Irishness.

Dónal grew up in Belfast in the 1950s and 1960s in a family in which Irishness was given a rather low profile:

My father was a trade unionist. He wasn't a classic Irish Nationalist as such [...]. So even though I was brought up in 
a Catholic home, I wasn't brought up in an Irish Nationalist home. You know, the home environment wasn't particularly Nationalistic or Irish-ish. My home wasn't decorated with Tricolours; we didn't have like pictures of [the Irish Socialist and a leader in the 1916 Easter Rising] James Connolly; or we didn't discuss, you know, 'the British has been really bad' or 'the police has been really bad'; it was none of that. 'Cause my father recognised that even though the police were anti-Catholic in many cases, you needed police in any state. [...] I wouldn't have been brought up with the kind of romanticism a lot of people might have been brought up with, of Irishness. You know, of the Irish language, of the Irish culture and so on. We had very little of that at home. [...] Nothing, nothing particularly Irish in our house!

Years later at the onset of the Troubles in 1969, Dónal was in his mid-teens and had up to that time 'never had any sense at all, whatsoever' of any local trouble. For example, in order to get to his Catholic grammar school, Dónal had taken the bus down the Falls Road every day and then walked straight across Protestant West Belfast, wearing a school uniform clearly indicating that he was pupil at a Catholic school and hence probably also a Catholic. Yet, as Dónal insisted, 'I don't remember ever a problem, ever!' But then, after the summer of 1969, there was one occasion:

I was actually walking back from school across the other way, back to the Falls. And I remember somebody; he didn't actually stop me, but he looked at me as I walked across. And because the Troubles had broken out, I was conscious of it. And he didn't really do anything. He just kind of stared at me. [...] I don't even think he said anything. He was young, but he was bigger than me. And I thought, 'This guy knows I'm a Catholic.' And that was the first time I really kind of thought about it. Hadn't really been aware of it up to that point. [...] And I just ran. He didn't chase me or anything. I just got that fear. And I thought, 'I'm not gonna go this way anymore, too risky.' So I went into town and came out again instead of coming across. [...] You know, routes that I felt were safe. So that was my kind of first feelings of change.

This event was soon followed by another that for Dónal exemplified 'a fundamental change.' Dónal recalled that there was a pupil at his school who was a cadet in the parachute regiment of the British Army. One day his class mates:

pushed him in the toilet block, and they attacked him. He was a pupil at the school, in the classes that they were in. And up until this point in time, you know, when the army first arrived in Belfast, they were welcomed on the streets in [Catholic] West Belfast, particularly around the Falls; cups of tea, whatever they wanted. It was only when the government changed tactics and started to oppress that things changed. And he wasn't even serving in the army; he was only a cadet! And these guys all attacked him. [...] I remember the incident very well, vividly. 'Cause I remember thinking, 'But these guys were all playing football last week! What's different?' I hadn't really appreciated the importance of the changes that were going on. So to me that was like a fundamental change that happened. Suddenly, somebody that they were playing with, somebody that had been part of their team was suddenly no longer part of the team, was an enemy! Somebody who had actually done nothing on an individual basis to deserve the attack was being attacked!

In the months to come, the issue of taking sides became ever more important. After the summer of 1969, as Dónal remembered:

There was a fear of attack by Protestants because there had been attacks on parts of Catholic West Belfast in Bombay Street, Conway Street and so on, by parts of the police and Protestant mobs. And there was a fear in Catholic areas that this could happen again. So there was a whole defence mechanism based around local vigilante-type arrangements. [...] So every area formed what was called 'Citizens' Defence Committees.'

These committees used burnt-out vehicles, pieces of concrete and other materials to barricade their local areas and then policed these barriers day and night. However, when the British Army imposed internment (i.e. imprisonment without trial) in August 1971, 'there was a feeling that Citizens' Defence Committees, barricades, barriers wasn't going to be enough. You needed to fight back with guns.' What followed were the beginnings of a recruitment drive for young people to join the Provisional IRA. As Dónal recalled, he once became part of this recruitment drive himself when the young people in our area were all called to a meeting in the house of a known Republican sympathiser.' So Dónal went, and while the whole issue was presented by an adult in a very reasonable, rational way,' it was enough for Dónal to realise that this was 'a recruitment drive for something that I didn't want to be involved with.' Hence Dónal left and did not get involved.

However, he did become increasingly involved with playing Irish music, and this was related to the Troubles as well. Before the Troubles, the town centre was Belfast's entertainment hub, with its offering of dancehalls and pubs featuring live music. Dónal recalled, 'You would have had very, very little in your local area.' Yet once the bombing started, people tended to associate in their local areas. This led to a huge growth in local entertainment as well as in shebeens (i.e. illegal drinking dens). It was within such shebeens and social clubs in West Belfast that Dónal ended up performing with Irish folk bands.

In these places, Dónal remembered, 'you would have been expected to do rebel music. That's what people wanted! And if you didn't want that, you were stuck with it anyway because everybody else wanted it!' Hence, Dónal and his mates often performed songs that he would have preferred not to sing. But given the lack of jobs in conditions of high unemployment Dónal was stuck with these songs and venues: 'the thing was if you didn't play those places you were very restricted as to where you could play, and you would probably not have earned very much money. So it was an economic decision, but it went against all my principles.' As confirmed also by other informants, a typical night progressed somewhat as follows:

Certainly the first half, you would do better-quality material. I mean there is some very beautiful rebel material. It's not necessarily all blood-and-guts. Some of it is superb, you know? And stuff that I would quite happily do anywhere, where people weren't offended by that. But in the first half, you would have done all your best material. Maybe traditional music, and whatever was going. Trying to get people to listen, you know? 'Cause anybody can get up and do rebel music once a crowd have got the blood up. Because it doesn't matter. They all sing with you anyway. So they drown you out. But if you want to distinguish you from the next band, you had to play your best material in the first half. So that's generally what you did. And the second half didn't matter. You just started playing the rebel stuff. And as the night progressively went on, you played more and more - outrageous, in my opinion, 'cause more blood-andguts towards the end of the night. And you really got into the very heavy stuff. So people would be on their feet, standing on their tables, jumping up and down. Roaring and rambling, and smashing their bottles on the floor. That kind of thing. Quite scary, actually. Oh, it is. Imagine a crowd of people standing on their tables, shaking their bottles whenever you give a particular song. Puh! It's abhorrent! You know, and you're rising all these people up! God, when they leave the place, what are they gonna do? That's the sort of thing. I always kind of wonder. Like, what 
happened after they -. It's very scary, thinking those thoughts, you know!

While - as Dónal put it - these nights 'were bad enough,' 'other nights were worse' when the IRA would suddenly appear on stage wearing balaclavas and brandishing guns because they were going to make a statement, and 'you had no idea they were gonna be there':

Most of them would have been masked, but the person making the speech might not have been masked. They may have been, you know, one of the political people [of Sinn Féin] as opposed to an actual [volunteer] [...] And they would have been reading out, 'This is what you have to do. And here is what we're doing.' You know what I mean? Urging people to support them. [...] And, I mean, you were preaching to a group of people who were feeling that way anyway! It wasn't a difficult thing to do. And every time, 'Oh yeah,' roared and stamping their feet. Quite a frightening thing to be in it, you know? Imagine if you [being a German] were back in the Third Reich? And standing there, and you got all of this stuff happening, and you don't wanna be there, but you are there! And you are not gonna be different, you gonna be banging the bottles as well and stamping your feet. You're standing on the stage, there is no way you gonna be sitting and saying, 'I don't wanna be here!' You gonna be saying, 'Yeah!' You know, of course you are. You are only a human being.

After years of being involved in these events, Dónal chose not to play in the clubs anymore because he was not comfortable with such political enthusiasm. He was then part of another Irish folk band that:

played all over Northern Ireland at that time. In fact, we made a point of trying to stay away from West Belfast. It was hard work because the biggest opportunities were in West Belfast. But by and large, we worked outside that. [...] Just to get away from being connected with the rebel thing.

While Dónal thus managed to personally 'get away from being connected,' his overall sense of ethnic identity did not cease to be affected by the persisting link between Irishness and 'the rebel thing.'

For the greater part of our series of interviews, Dónal hence described himself (and could be thus experienced, e.g. when weeping) as having 'this identity crisis for a long time,' being 'very torn' between wanting to be Irish and being unable to identify with this identity because Irishness had become so closely associated with Republican violence. As Dónal put it in one of numerous variations:

I recognise that I was born a Catholic and brought up as a Catholic. And I suppose, there's an expectation that I would automatically identify with an Irish culture. [...] While I was young, I went to the Gaeltacht [i.e. Irish-speaking areas], learnt Irish at school, very strongly had those - strong affiliations with the language and music [through these Gaeltacht stays]. And still would have that! The actual identity of that with who I am, it didn't square up because of really the violence that occurred since 1969. And that was a formative time for me because I was fifteen, sixteen. And I'm not a violent person, and I can't, I couldn't connect the idea of being Irish with the violence of the IRA, irrespective of any justification; none of it ever justified itself to me. And so for people to declare themselves 'Irish' and kill people for it, you know, I just couldn't square that. So for me, I still have a real problem with it. I suppose underneath it all, I would love to say to people, 'I have a real strong Irish identity!' I mean, I have a strong affiliation with Irishness. But because, for me, it's been spoiled, tainted, ruined almost by the Troubles, I have a real problem saying it! [...] So I'm left in a very difficult position because I want to be Irish, but I've got a problem with all the violence. And that's really made it very difficult for me to overcome that. And I don't feel British at all! So what I chose to call myself was 'European.' I don't really feel that terribly strongly. But I feel that describes me better than - I can't call myself Irish, at the moment.

As Dónal thus clarified for me (and himself) on several occasions, 'If you had to be at war to be Irish, I didn't want that,' even though 'at the core it's sad that I can't identify with, I suppose, what I feel strongest about.' Yet Dónal simply did not 'wanna be lumped in with all that lot' who were 'killing people in my name.'

When extensively reflecting again on his position during our last interview, Dónal suddenly came to realise that his identity crisis did not actually consist in his Irishness being ruined by the Troubles but rather in being forced to answer a question that was important to others but not for him:

I think this is what happens. This is really the nub of it. I think people presume that you need to have an identity, which is associated with, you know, a culture: Irishness or Britishness or something. So it's other people that I respond to when they say to me, 'What are you?' 'Cause I don't think about it. [...] I mean all the forms that you fill in as well say, 'Are you Irish or British or what are you?' You have to tick boxes if you fill in an application form, and you have to say what you are. So whether you liked it or not, you were confronted by something that to me wasn't important. It is important to other people but not important to me. So I suppose what l've been saying is, it's a crisis for me because if I have to answer a question, 'Are you Irish, are you British?' I have to answer the question! 'Where were you born?' 'Were you born in Britain; were you born in Ireland?' I've got to answer the question! So you are confronted by it because other people presume that it is important or need to count it for some reason. Because they need to know how many Irish people, how many British people they've got in their work force or how many Catholics, how many Protestants they have. These things to me are not important. But I am confronted by them because other people expect me to have an answer. So, you know, it's a crisis in that sense. I'm only realising that having this discussion because you go down to the core of it. [...] I'm just being confronted by these things, 'Shit, what am I? I don't wanna be Irish. I am certainly not feeling British, ah, ah, ah [Dónal acts out his decision] 'European,' that's the easiest thing to tick.' [...] To prevent them putting me in a box that I don't wanna be in. And I don't wanna be described by somebody else as being either on their side or against them because here that's what it means: if you are Irish you are against this; if you're British against that. And I don't want that!

During our last interview, Dónal developed this as a new position whereas I interpret(ed) it as an additional facet of his complex identity in which, to my mind, two things came together: First, Dónal actually did have a strong affiliation with Irishness even though this identity 'associated with, you know, a culture' might indeed have been much less important for him than for other people, who nevertheless made him self-classify in such terms. Second, the growing ethnicisation in the course of the Troubles had become highly problematic for Dónal given that the label 'Irish' had accumulated so many violent political implications because of the Irish-Republican 'armed struggle.' And as Dónal strongly rejected these implications, he could no longer unproblematically call himself 'Irish.'

\section{Between the lines: dissenting from the Republican socio- culture of trauma}

It is tempting to simply individualise Dónal's troubles with Irishness and interpret (if not dismiss) them as symptoms of 
a purely personal failure to cope with traumatic experiences. As we will see, this was actually one of the more benign reactions with which Dónal was confronted in interactions with significant others. However, I suggest conceiving these difficulties as also profoundly socio-cultural, indicating a substantial mismatch between the hegemonic structures within the specific socio-culture of trauma in Catholic West Belfast and dissenting attempts by individuals such as Dónal to come to terms with pain and suffering.

During numerous encounters in Catholic West Belfast, it became quite clear to me that the local socio-culture of trauma was generally dominated by trauma narratives couched in terms of Irish Nationalism and, especially, Republicanism. The history of Irish Nationalism and Republicanism has, of course, not been monolithic, entailing various strands that have been divided on controversial issues such as the specificities of the aspired political goals and the legitimate means to achieve them. ${ }^{1}$

However, despite all variation, there has been a core of Irish Nationalist and, especially, Republican thinking which can be characterised as follows (see McGarry \& O'Leary, 1995: 21-35, Patterson, 1997: 101): The island of Ireland is the historical homeland of one nation, the Irish people. After centuries of oppression by the British state this nation should have been granted its entire territory in accordance with the principle of national self-determination. Yet the Irish national revolution in 1918-1921 has remained incomplete. What became 'Northern Ireland' was artificially retained by the United Kingdom and subsequently developed into a place where Catholics were treated like second-class citizens and exposed to sectarian violence by the local Protestant majority and its state apparatus. However, partition and local sectarianism ultimately were not the fault of Protestants but the British state, in whose imperialist interest it was to retain control over this part of the island. For this purpose, the British state fostered the sectarian divide by granting privileges to local Protestants. It was ultimately the oppressive British state that was responsible for discrimination against victimised Irish Catholics and hence for their collective trauma. In the Republican heartland of Catholic West Belfast, I often heard this trauma narrative accompanied by an honestly regretful insistence that ultimately the Republican 'armed struggle' had become the only option given that lawful protest like the civil rights movement was ineffectual, as the law-makers were in fact also the law-breakers and unwilling to reform.

It goes without saying that this Republican trauma narrative legitimising violence was by no means the only way in which painful experiences were represented within the local socioculture of trauma. In fact, Dónal's case shows that alternative readings existed. Yet, I contend that this briefly sketched Republican discourse was hegemonic in that it was the loudest and most powerfully backed by those with guns. This perception is supported by several ethnographic studies focusing on Republican violence in its communal setting. Using the example of an anonymised Catholic working-class enclave in Belfast, Burton (1978) shows how Republicanism managed to establish political legitimacy within its constituency by crafting its particular ideology out of the general social consciousness of Northern Irish Catholicism. Similarly, Sluka (1989) describes for parts of Catholic West Belfast how the dynamics between social control and vigilante policing by paramilitaries and variable communal responses ensured popular support - hard or soft, conditional or unconditional, active or by default - for Republicanism. Focusing more on bodies as both objects and subjects of guerrilla warfare, Feldman (1991) equally provides lengthy descriptions about the formative exercise of

\footnotetext{
${ }^{1}$ For detailed discussions about the various strands within Irish Nationalism and Republicanism see Cronin, 1980; McGarry \& O’Leary, 1995; Patterson, 1997.
}

political violence within and across communal boundaries. What these studies show is that, while Republicanism has neither been homogenous and unchanging nor the only way of locally making sense of political experiences, its complex narrative has nevertheless been considerably widespread, often been popularly supported and, in that sense, become sufficiently hegemonic within radicalised enclaves such as Catholic West Belfast.

Dónal's personal way of making sense of traumatic experiences thus did not take place in a vacuum. The mere fact that his reading of local violence did not square up with the hegemonic Republican discourse meant that he was effectively reading 'between the lines' of empowered meanings: whereas the Republican trauma narrative emphasised the collective suffering of a victimised community due to political oppression, Dónal highlighted the individual suffering of victims from all communities, 'irrespective of any justification; ' whilst Republicans weighed individual suffering differently in ascribing victimhood only to Irish Catholic victims of discrimination and conceptualised casualties on the other side as a deplorable but necessary result of war, Dónal insisted that 'all of us have been impaired; we are all painted shades of the victim colour.' In short, in contradistinction to the hegemonic Republican trauma discourse, Dónal activated an alternative morality that emphasised the universal pain of personal suffering rather than the political injustice of collective victimhood.

Yet in so doing, Dónal also de facto established a counternarrative, which unintentionally positioned him 'between the frontlines' of political power that were intelligible, relevant and meaningful to most local actors (or rather, the lines that most locals appeared to publicly toe and thereby reproduced). Without intending to do so, Dónal became a dissenter merely by deviating from the hegemonic Republican reading within the socio-culture of trauma in Catholic West Belfast. As such, Dónal's dissenting view constituted, at best, an irritation and, at worst, a threat simply because it did not adhere to well-established political categories of friend and foe. This was to have immediate consequences for Dónal's encounters with other locals, whose responses ranged from incomprehension to repudiation to threatening silence.

When reflecting on our interviews, Dónal repeatedly mentioned that he did not know how many people there were like him as this was not a topic about which he frequently and extensively conversed with others. Apart from me, Dónal seemed to have discussed the issue only with his wife and mother-in-law. However, these encounters had not been very productive given that - as Dónal put it - 'my wife doesn't really understand it and thinks I'm a coward':

I can't talk to my wife about it because she doesn't understand! Because she doesn't have that same difficulty. I mean, she understands a little but can't really; just thinks I'm being - I don't know what she thinks I'm being. She doesn't really identify with me on that point.

This was the case, Dónal explained, because his wife was strongly Republican and hence felt 'comfortable with that culture and that identity. She has no problem with it. It's me that has the problem.' While these encounters appear to have been characterised by benevolent incomprehension, Dónal's discussions with his mother-in-law turned more confrontational:

I've had a row with her about it. She can't believe that I would hold a totally different view. How can I? What? You know, it's almost as if it's shock for her to believe that a Catholic with a Nationalist [community] background doesn't support the armed struggle. 'But look what they did to us!' is what they usually think. 'Look at what they did to us! Burnt mother out of her house twice!' And then this and then that, and look at this, 
you know. 'And you're telling me you can't support?' There's no comprehension there, you know.

Though Dónal had engaged in a few conversations about his traumatised Irishness, generally he kept quiet and had done so for many years, as he felt 'silenced' by Republicans:

The freedom of speech is very truncated. In the early part of the Troubles, anybody that tried to speak their own mind was very quickly silenced. [...] I think some were killed. But I mean most people would have been sent away, removed from the area. You know, 'If you're not one of us, you're out. You're not part of the group any longer.' And that, to some extent, to a large extent, did happen. And people were afraid to speak out. You know, they were terrified. Because people had guns and you didn't. And if you were to speak out, they might come and shoot you.

Dónal himself felt terrified to speak out, as he feared having 'a discussion with the local militia, where you didn't agree.' Dónal was well aware that he might be exaggerating the actual situation and that some people would argue that nothing would have happened. But, as Dónal stressed, 'it was nevertheless my feeling. And the perception that you might get killed as a result of speaking out is enough to stop you speaking out. So it doesn't actually matter whether or not it really would have happened.'

It is against this background of reconstructed informational content that the interactional context of my encounters with Dónal can finally be revisited. This background was characterised, on the one hand, by a socio-culture of trauma strongly dominated by Republicanism and, on the other hand, by Dónal's dissenting views on suffering which, in their mutual interaction, led Dónal to a state of incomprehension, silence and isolation. Based on the assumption that these interpretations are sufficiently appropriate, the interactional dynamics between Dónal and me also begin to make sense: Given that Dónal felt silenced by the threat of Republican violence, he was simply not accustomed to an interactional context, in which somebody empathically asked questions about identity and suffering without already being positioned (and judging) according to local standards. This explains why Dónal did not immediately reproduce well-rehearsed positions, like many of my Nationalist/Republican informants, but rather tentatively began exploring his feelings and attitudes. Conversely, the fact that our encounters enabled Dónal to tell his story for the first time in his life supports the interpretation that there existed a profound mismatch between individual attempts to literally come to terms with traumatic experiences and locally hegemonic forms of trauma management, which had effectively silenced Dónal. The analysis of informational content and interactional context in their mutual interrelatedness thus stabilises my overall interpretation, ultimately highlighting that the extra-ordinariness of our talk was, itself, symptomatic of the ordinariness of local silence that generally existed beyond our encounters.

\section{Conclusion: the politics of meta-trauma}

Through our encounters, Dónal indeed came across as a sensitive man. Yet his troubled sense of ethnicity and his continual difficulties in coming to terms with his traumatic experiences, to me, were not simply symptoms of a personal failure to cope psychologically. Instead, his inability to integrate experiences of suffering into his personal lifeworld was to a considerable extent also socio-culturally conditioned by the very structures of this lifeworld. Given that Dónal did not neatly fit into the socio-culture of trauma in Catholic West Belfast operating under the shadow of hegemonic Republicanism, he was made into a dissenter who, in his own perception, lacked the necessary agency to move on.
Analysing the impact of the Salvadoran Civil War on mental health, Martín-Baró (1994: 103-167) emphasises that war contexts typically lead to repetitive exposures to violence and an ever expanding social polarisation and radical differentiation between 'us' and 'them' that ultimately implicate 'the whole scope of existence' (Martín-Baró, 1994: 113). It is in the dehumanising context of such a 'normal abnormality' that people have to construct their identities in daily life, often leading to socio-culturally induced psychological disorders that he identifies as dialectically instituted forms of 'psychosocial trauma' (1994: 108-135). This conception of trauma seems directly applicable to the situation in the North of Ireland and, particularly, to Dónal's experiences. Yet while MartínBaró does not further specify different types of such traumata with regard to their varying positionalities vis-à-vis the polarisation of life during war, Dónal's traumatic experiences and his identity troubles seem to allow such a further step to be taken.

It is in this sense that I suggest the term 'meta-trauma' to refer to an emotional affliction, characterised by the socio-culturally conditioned 'second' psychosocial trauma of persistently failing to integrate one's own traumatic experiences within a politically hostile environment. This meta-trauma is trauma proper as outlined in the introduction, i.e. psychological suffering resulting from serious threats to one's physical integrity, but these threats are directly related to the fact that the meta-traumatised person's attempts to come to terms with traumatic experiences during political conflict significantly diverge from the hegemonic trauma narrative upheld by those with the guns. Meta-trauma is thus a 'second' trauma of silence, emerging from struggles surrounding the very definition of the 'first' trauma. As such, meta-trauma continuously prevents the afflicted to verbalise their painful experiences in the form of 'trauma stories' - a process that psychiatrists such as Mollica (2006) have identified as crucial for self-healing.

Towards the end of our interaction, Dónal felt somewhat empowered through his final interpretation that he actually only had a crisis because he had been confronted 'by something that to me wasn't important,' namely, by external requests to identify himself in terms of ethnicity. As I have argued, I am sceptical that this was really the whole story, as I suspect that there was also another, ambivalent side to this, namely, his desire to call himself 'Irish,' even as he explicitly rejected this identification because of its accumulated connotations of violence.

However, taking up Dónal's idea that relating one's own afflictions to the positions of significant others may lead to self-empowerment, it is worth emphasising that other locals - such as his wife - did not necessarily have fewer problems than Dónal because they were more capable actors but rather because they dissented from the dominant socio-culture of trauma to a lesser extent and thus were less positioned 'between the lines.' In other words, the extent to which individuals experienced meta-trauma also appeared to be a political issue correlated to the degree of individual deviance from the local socioculture of trauma rather than being merely dependent upon individual capacity to cope with suffering. Paradoxically, socialising metatrauma as a political issue rather than individualising it as personal failure allows for a reintroduction of individual agency and selfempowerment. Insisting on the politics of meta-trauma in (post-) conflict societies helps to specify more precisely the socio-cultural place of this affliction. It may turn out that such an insistence can simultaneously help to put the phenomenon of meta-trauma itself in its place and thereby allow suffering people such as Dónal to leave at least some of their pain behind.

\section{References}

Aggarwal, N. K. (2007). Exploring identity, culture, and suffering with a Kashmiri Sikh refugee. Social Science \& Medicine, 65, 1654-1665. 
American Psychiatric Association. (1994). Diagnostic and statistical manual of mental disorders: DSM-IV. Washington, DC: American Psychiatric Association.

Bracken, P. J., Giller, J. E. \& Summerfield, D. (1995). Psychological responses to war and atrocity: the limitations of current concepts. Social Science E Medicine, 40,1073-1082.

Buckley-Zistel, S. (2006). Remembering to forget: chosen amnesia as a strategy for local coexistence in post-genocide Rwanda. Africa, 76(2), 131-150.

Burton, F. (1978). The politics of legitimacy: Struggles in a Belfast community. London/ Boston: Routledge and K. Paul.

Coakley, J. (2007). National identity in Northern Ireland: stability or change? Nations and Nationalism, 13(4), 573-597.

Coulter, C. (1999). Contemporary Northern Irish society: An introduction. London/ Sterling: Pluto Press.

Cronin, S. (1980). Irish nationalism: A history of its roots and ideology. Dublin: The Academy Press.

Das, V., Kleinman, A., Lock, M. M., Ramphele, M., \& Reynolds, P. (Eds.). (2001). Remaking a world: Violence, social suffering and recovery. Berkeley: University of California Press.

Das, V., Kleinman, A., Ramphele, M., \& Reynolds, P. (Eds.). (2000). Violence and subjectivity. Berkeley: University of California Press.

Doherty, P., \& Poole, M. (2000). Living apart in Belfast: residential segregation in a context of ethnic conflict. In F. W. Boal (Ed.), Ethnicity and housing: Accommodating differences (pp. 179-189). Aldershot: Ashgate.

Eames, R., \& Bradley, D. (2009). Report of the consultative group on the past. Belfast: Consultative Group on the Past.

Feldman, A. (1991). Formations of violence: The narrative of the body and political terror in Northern Ireland. Chicago: University of Chicago Press.

Frank, G. (1995). Anthropology and the individual lives: the story of the life history and the history of the life story. American Anthropologist, 97(1), 145-148.

Gjerde, P. F. (2004). Culture, power, and experience: toward a person-centered cultural psychology. Human Development, 47, 138-157.

Glaser, B. G., \& Strauss, A. L. (1967). The discovery of grounded theory: Strategies for qualitative research. Chicago: Aldine.

Gramsci, A. (1971). Selections from the prison notebooks of Antonio Gramsci. London: Lawrence \& Wishart.

Hammack, P. L. (2008). Narrative and the cultural psychology of identity. Personality and Social Psychology Review, 12(3), 222-247.

Herman, J. L. (1992). Trauma and recovery: The aftermath of violence - From domestic abuse to political terror. New York: BasicBooks.
Kleinman, A., Das, V., \& Lock, M. M. (1997a). Introduction. In A. Kleinman, V. Das, \& M. M. Lock (Eds.), Social suffering (pp. ix-xxvii). Berkeley: University of California Press.

Kleinman, A., Das, V., \& Lock, M. M. (Eds.). (1997b). Social suffering. Berkeley: University of California Press.

Martín-Baró, I. (1994). Writings for a liberation psychology. Cambridge, MA: Harvard University Press.

McGarry, J., \& O'Leary, B. (1995). Explaining Northern Ireland: Broken images. Oxford/ Cambridge, MA: Blackwell.

Mollica, R. F. (2006). Healing invisible wounds: Paths to hope and recovery in a violent world. Orlando: Harcourt.

Patterson, H. (1997). The politics of illusion: A political history of the IRA. London: Serif.

Peacock, J. L., \& Holland, D. C. (1993). The narrated self: life stories in process. Ethos, 21(4), 367-383.

Sluka, J. A. (1989). Hearts and minds, water and fish: Support for the IRA and INLA in a Northern Irish ghetto. Greenwich: JAI Press.

Social Services Inspectorate. (1998). Living with the trauma of the troubles. Belfast: Department of Health and Social Services, Northern Ireland.

Summerfield, D. (1999). A critique of seven assumptions behind psychological trauma programmes in war-affected areas. Social Science \& Medicine, 48, $1449-1462$.

Volkan, V. D. (1991). On chosen trauma. Mind and Human Interaction, 4, 3-19.

Young, A. (1995). The harmony of illusions: Inventing post-traumatic stress disorder. Princeton, NJ: Princeton University Press.

Zenker, O. (2008). Irish/ness is all around us: The Irish language and Irish identity in Catholic West Belfast. Unpublished PhD thesis. Max Planck Institute for Social Anthropology/Institute for Social Anthropology. Halle/Saale: Martin Luther University Halle-Wittenberg.

Zenker, O. (2009). Autochthony and activism among contemporary Irish Nationalists in Northern Ireland, or: if 'civic' nationalists are 'ethno'-cultural revivalists, what remains of the civic/ethnic divide? [and postscript by Joep Leerssen and reply]. Nations and Nationalism, 15(4), 696-722.

Zenker, O. (2010). Language matters: reflexive notes on representing the Irish language revival in Catholic West Belfast. In O. Zenker, \& K. Kumoll (Eds.), Beyond Writing Culture: Current intersections of epistemologies and representational practices (pp. 121-138). Oxford/New York: Berghahn Books. 